\title{
SPECIAL ECONOMIC ZONES IN THE CONTEXT OF REGIONAL DEVELOPMENT ${ }^{1}$
}

\author{
Tomasz Józefowski ${ }^{1}$, Andrzej Młodak² \\ ${ }^{1}$ Statistical Office in Poznań, Centre for Small Area Estimation \\ Wojska Polskiego 27/29, 60-624 Poznań: Poland \\ T.Jozefowski@stat.gov.pl \\ ${ }^{2}$ Statistical Office in Poznań, Centre for Small Area Estimation \\ Branch in Kalisz, PI. J. Kilińskiego 13, 62-800 Kalisz: Poland \\ The President Stanisław Wojciechowski State University of Applied Sciences in Kalisz \\ Nowy Świat 4, 62-800 Kalisz: Poland
}

A.Mlodak@stat.gov.pl

\begin{abstract}
Special Economic Zones (SEZ), areas where companies can operate in preferential conditions, have been created to boost the economic development of particular regions. The article describes an attempt to assess the connections between and the impact of the way special economic zones function and the economic development of municipalities (Pol. gmina) where they are located. In particular, the authors discuss the key characteristics of these zones that are directly related to the prosperity of municipalities where the companies are based as well as elements of current policies and development strategies pursued by the municipalities that affect the economic reality of the zones. The second part of the study involves an econometric analysis of the socio-economic development of municipalities of Podkarpackie province (which is evaluated by means of a comprehensive taxonomic measure) in terms of a classic measure of wealth, i.e. municipal revenues per capita, and depending on whether or not a given municipality hosts companies belonging to a special economic zone. Based on this analysis, the authors draw conclusions about the importance of specific SEZs for the development of local communities.
\end{abstract}

Key words: special economic zones, regional development, taxonomic measure, regression analysis.

\section{Introduction}

In recent years special economic zones have become an important element to foster the sustainable development of many countries, especially those whose economies are still on the way to reaching the level comparable to that of the most development countries. From a formal point of view, as defined by Kołomycew (2008), a Special Economic Zone (SEZ) is a designated and non-residential area of a country, where companies can conduct economic activity under preferential conditions. This

1 The article is based on a paper delivered by the authors during the national conference entitled "Statistical identification of connections in socio-economic space", which was held on 14-15th June 2016 in Poznań. 
preferential treatment includes tax allowances, provision of land with infrastructure for economic activity and improved conditions of job creation.

SEZs are created in various parts of the world, especially in developing countries and, consequently, are the subject of many scientific studies. Omar and Stoever (2008), using the example of Malaysia, discuss the importance of technological development and policies to foster human capital in the functioning of SEZs. They conclude that the creation of SEZs may not lead to the structural transformation that developing countries expect, but, when efficiently managed, they can be a significant factor in the development of such countries. They argue that investments in human resources and technology development are necessary to stimulate SEZs.

Akinci and Crittle (2008) observe that economic benefits of EPZs' development can be either static (generation of direct employment and income, export growth and export diversification, revenue from foreign exchange, foreign direct investment and government revenues) or dynamic (creation of indirect employment, improvement of skills, female employment, technology transfer, "demonstration effect" arising from the application of "best practices", regional development). They note that the impact of static benefits is obviously stronger in poorer countries, where human, capital and government resources are scarce. On the other hand, the dynamic benefits are harder to measure. In this paper we show that using a complex taxonomic measure, which takes into account mutual connections between diagnostic features describing many such benefits, one can, to some extent, overcome these difficulties.

A complex review of the history of SEZ creation, their types, models of SEZ-related creation of new jobs, investments as well as social and environmental sustainability resulting from the existence of SEZs in various countries (Bangladesh, China, Honduras, Kenya, Lesotho, Madagascar, Mauritius, etc.) can be found in the monograph edited by Farole and Akinci (2011). The authors describe how the growing importance of preferential trade agreements presents both challenges and opportunities for programmes of export-processing zones (EPZ - a specific class of SEZ). Another interesting question addressed in this book is the Chinese cooperation programme of transferring new organizational and technical solutions and other economic incentives to overseas EPZs, especially in Africa. The Chinese programme was deeply analysed by Bräutigam and Tang (2014), who identified the most important factors which contribute to the development of EPZs participating in this program and their potential for fostering structural transformation in Africa.

As noted by Ambroziak (2009), special economic zones in Poland operate by virtue of the Special Economic Zones Act of 20 October 1994 (Journal of Laws of 1994, No. 123, item 600, with later amendments). The act defines the objectives of SEZs as a way of accelerating regional development, among others, by (see Ambroziak 2009):

- developing selected fields of economic activity,

- developing new technological solutions and their application in the national economy,

- developing export,

- increasing the competitiveness of products and services,

- exploiting the existing industrial capital,

- creating new jobs,

- exploiting unused natural resources in a sustainable way.

Favourable regulations facilitating economic activity in special zones provide a way to support specific areas of economic activity, develop tools and technical equipment, implement modern technologies, create new jobs, and indirectly, develop transport and municipal infrastructure, construction activity in a region where companies belonging to a special economic zone operate. All 
these processes contribute significantly to increasing the standard of living and the wealth of the local population. It is worth noting (Miłaszewicz 2011) that the SEZ regulations have been modified several times in order to adjust them to the relevant standards in the European Union (which Poland joined in 2004) and to increase the attractiveness of the SEZs for investors, including the existence of government support.

The existence of special economic zones provides many benefits: (see, for instance Domański \& Gwosdz 2005):

- they are an effective tool of regional policy, which is used to equalise developmental opportunities,

- they play a significant role in improving the general economic system and the economic situation of local labour markets,

- they stimulate the activity of employers and their capacity to adapt to changing conditions of the labour market,

- they are a way of fostering new production investments,

- they have a major influence on the development of economic infrastructure,

- they contribute to an increase in production, which in turn leads to a rise in GDP,

- they provide benefits for the state budget: they create new jobs, generate personal income tax revenue, stimulate consumption, and consequently, generate higher VAT revenue.

However, the existence of special economic zones is also associated with certain threats. The most important ones include:

- the 'idle run' effect - when investments are made irrespective of the existence of SEZ, rendering its establishment unnecessary,

- the substitution effect - when an enterprise which has started business activity in a SEZ has discontinued or significantly reduced its activity elsewhere,

- the displacement effect - when aid provided to companies in SEZs gives them a competitive advantage, which is used to push other companies in the same field out of business,

- the enclave effect - when companies based in a SEZ are not connected with the surrounding region; they rely on materials and parts delivered from outside the region, which are then sold outside the region,

- ineffective location - the creation of subzones in locations preferred by investors, which are relatively well prepared for investments, have well-qualified workforce and are often characterised by a relatively high level of economic development,

- excessive tax breaks - decrease the state budget as a result of lower revenues from personal income tax and from corporate income tax.

The efficiency of the way SEZs function in Poland has been studied by many Polish researchers. For instance, Miłaszewicz (2011) provides an interesting analysis and concludes that the achievement of the main goals of their establishment measured in terms of the value of investment and the number of new jobs was a rather slow process, which took about 10 years. Moreover, the dynamics of these measures is sensitive to the current economic situation. Miłaszewicz (2011) also observes that changes in the structure of investment were rather favourable, resulting in a moderate growth in industries relying on advanced techniques. Nazarczuk (2013) - on the basis of available statistical data and opinions of SEZs' management staff - investigated the effects of government support offered to Polish SEZs. When SEZ managers were asked about which aims of SEZs were being achieved to the greatest extent, they mentioned the creation of new jobs in areas experiencing economic depression, the reduction of unemployment in less developed areas and the attraction of capital to stimulate economic activity in some areas. He also analysed the efficiency 
of public support provided to firms in SEZs in terms of tax revenue obtained from them; he found that, when taking into account both public and non-public support measured in terms of direct efficiency (taxes and payments) and indirect efficiency (social and health security contributions, personal income tax of employees, etc.), 1 PLN of subsidy can generate up to 4 PLN of additional revenue for the state budget.

Kryńska (2000) discusses advantages and drawbacks of government intervention in SEZs. According to her studies, although the positive effects of public subsidies (provided under certain conditions) usually outweigh the distortionary effect of intervention, one can observe that government intervention has either no effect or a negative effect on the performance of subsidised industries. She also observes that SEZs are associated with the existence of a dual labour market, each one governed by different principles, causing employees and employers to act differently in an effort to adapt to the different conditions.

At the moment there are 14 special economic zones in Poland. They are mainly located in regions characterized by high unemployment, post-industrial economy or intensive industry restructuring, often causing negative side effects. Figure 1 shows spatial distribution of SEZs in Poland. The figure shows municipalities containing companies belonging to specific SEZs.

As can be seen, special economic zones are not contiguous areas nor do they coincide with the administrative division. In fact, they are groups of companies united by common economic goals and playing an important role in regional development, which is the reason why they enjoy the same preferential treatment. Consequently, in order to assess the effectiveness of SEZs, it is necessary to evaluate the actual impact of SEZs on the socio-economic situation of spatial units where companies belonging to these special zones are located. However, in view of the discrepancy between the spatial distribution of SEZs and the country's territorial division (which is the basis of data collection and aggregation), the phenomenon poses a particular research challenge. Attempts undertaken and described in the literature so far (Kudełko 2006; Lizińska \& Marks-Bielska 2013; Golik \& Kątnik-Prokop 2014) only focus on results of companies operating in SEZs taken as a whole rather than, more crucially, on how results of activities conducted by these companies affect the development of particular municipalities where they are located and how particular SEZs vary in terms of this impact (whether it can be classified as dynamic benefits according to the above mentioned typology introduced by Akinci and Crittle (2008)). Similarly, Pastusiak (2011) and Pastusiak and Keller (2014) discuss the usefulness of the enclave model, which compares capital flows to a SEZ and the impact of its production on the economy outside the SEZ. This attempt defines net advantages (net flows) as a difference between financial flows in the economy with SEZ and without SEZ, multiplied by the shadow cost index. However, it does not take into account social and economic effects of SEZs' activity in relevant areas in a complex way. 


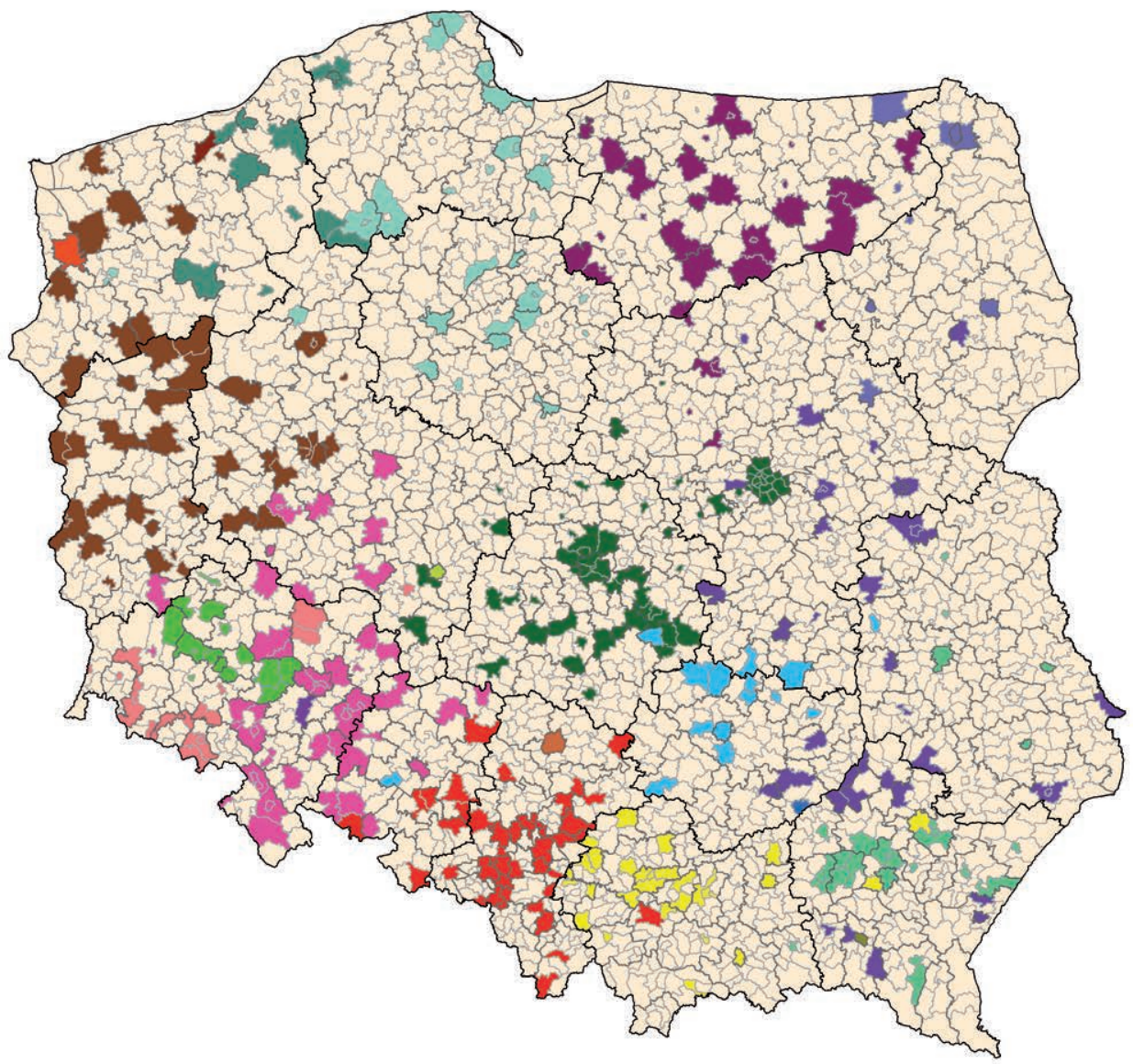

Municipalities which contain subzones belonging to special economic zones in 2014
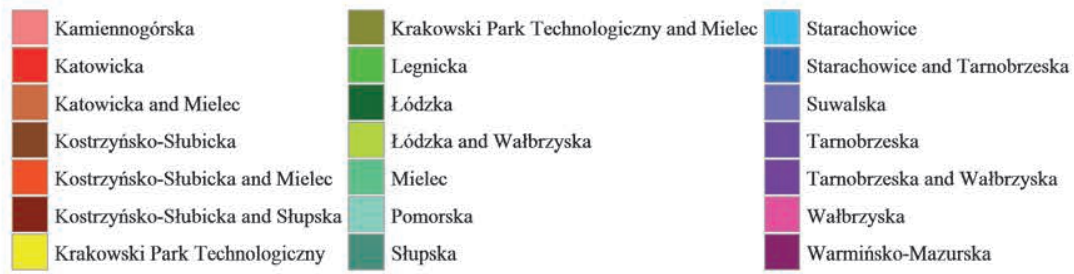

Figure 1. Distribution of special economic zones in municipalities in 2014

The first attempt to investigate this aspect of the problem was undertaken by Józefowski and Szymkowiak (2015), who used a generalized measure of distance to create a linear ordering of districts (NUTS 4) containing special economic subzones in Podkarpackie province in terms of the labour market situation. However, that modelling attempt still did not take into account direct connections between spatial areas and special economic zones. For this reason, the present article describes a study involving an econometric model which accounts for both these aspects using data about 
Podkarpackie province, at the level of municipalities (NUTS 5). The response variable in the model is the complex measure of socio-economic development of municipalities in Podkarpackie province; explanatory variables - depending on the availability of information - include municipal revenues per capita and the binary variably indicating whether a given municipality contains companies belonging to a particular SEZ. It is worth noting at this point that Podkarpackie province contains enterprises that belong to three SEZs: Kraków Technological Park, Mielec Special Economic Zone and Tarnobrzeg Special Economic Zone. In addition, in one municipality (Krosna) there are enterprises belonging to two different zones: Kraków Technological Park and Mielec SEZ. These specific details are also accounted for in the model. Thanks to this approach, it will be possible to demonstrate that municipal revenues, despite being the most popular choice, need not be the only and most important measure of a municipality's development ${ }^{2}$.

The article consists of three main parts. In the following section (2), we discuss the principles and methods of selecting and verifying diagnostic features used to construct a complex measure of development of municipalities and describe the procedure of calculating it. In section 3 we present the econometric model based on this complex measure. Results obtained using the model will be analysed in section 4 . This will be followed by conclusions and implications for further research.

\section{Construction of a complex measure}

As mentioned earlier, the response variable in the analysis was the synthetic measure of socioeconomic development of municipalities. It was constructed on the basis of the taxonomic concept of univariate description of multivariate phenomena. Each unit (in this case - a municipality) is described using numbers reflecting specific aspects of the phenomenon of interest. The measure is constructed in multiple stages. Details of the method are provided in article by Młodak, Józefowski and Wawrowski (2016) or book by Młodak (2006a). What follows is a concept outline of the construction procedure.

The first step involves selecting input variables. They need to be measurable, logically related to the complex phenomenon of interest and have the following properties: sufficient quality, information diversity, relevance for the phenomena of interest, completeness of information about all aspects that have a significant influence on a given phenomenon of interest, lack of definitional ambiguity, logical relationships between variables. Input variables should also serve as indicators, as this property eliminates a number of inconveniences related to certain natural disproportions between different objects of interest. For example, towns with district rights tend to differ in terms of demography and housing characteristics from rural municipalities. The source of input data for the study was the Local Data Bank maintained by the Central Statistical Office. A set of 38 input indicator variables was selected, describing various aspects of socio-economic life in municipali-

2 With respect to analyses of socio-economic development conducted at the lowest territorial level, i.e. at the level of municipalities, the term "regional development" is usually replaced with "local development". However, drawing a clear distinction between what is regional and what is local is as difficult as it is to define the concept of regional development. In fact, many researchers tacitly agree that the term "local" in this context refers to municipalities, but there is no doubt that the area of a municipality can have its own specific and unique character, and therefore fit the commonly used definition of "region" or "micro-region" (see e.g. Kapusta 1997). In addition, the present study investigates differentiation in socio-economic development within the province, which definitely deserves to be called a region. For this reason, we have decided to keep the term "regional". 
ties of Podkarpackie province in 2014, including municipal expenditures, communal and housing infrastructure, availability of services, etc.

The second stage consists in data verification. Its main purpose is to identify the most informative variables with the biggest discriminatory power with respect to the knowledge about the objects of study. Verification is conducted in two steps. First, variables are selected in terms of variability, which means eliminating variables exhibiting insufficient variation, i.e. those with little power to discriminate between objects of interest. A variable which is not sufficiently varied proves useless. In practical terms, variables whose absolute coefficients of variation are below a certain arbitrary threshold are eliminated. The commonly used threshold value is $0.1(10 \%)$. It is worth noting that all variables taken into consideration were characterized by sufficiently high variation.

The variables retained in the model are then tested for inter-correlation in order to eliminate excessively correlated data, which provide similar information content. In practical terms, it is necessary to analyse correlation coefficients of all possible pairs of variables. The starting point for this stage is the construction of the correlation matrix. In order to ensure the integrity of the taxonomic model (and all relationships between analysed variables - not only formal but also those expressed in terms of correlations), the inverse correlation matrix (Malina \& Zeliaś 1998; Młodak 2006a) was used. The approach involves calculating an inverse of the correlation matrix consisting of Pearson correlation coefficients $R$, i.e. $\mathrm{R}^{-1}$. Then the diagonal elements of the reverse matrix $R^{-1}$ are examined to check if they belong to the interval $[1, \infty)$. If these elements are too big - e.g. greater than 10 - it is indicative of a faulty condition number of the matrix $\mathrm{R}^{-1}$, which in turn means excessive collinearity. If only one variable has this property, it is eliminated. Otherwise, the goal of optimal elimination is to remove the minimum number of variables while making sure that all diagonal elements are less than 10. After verifying the original set of variables in terms of variation and correlation, it was possible to make the final selection of diagnostic variables.

The actual construction of the taxonomic measure requires the transformation and normalization of the selected variables. To this end, it is necessary to identify how the variables affect the objects of interest in the context of the complex phenomenon under investigation. Considering the direction of impact, diagnostic variables can be divided into:

- stimulants - variables whose higher values indicate a better state of the object in a given context;

- destimulants - higher values of a given variable correspond to a less favourable situation of the object in the context of the phenomenon of interest;

- nominants - variables with an optimal value level (inflection point), below which they behave like stimulants, and above which they function as destimulants or vice versa.

Listed below are the 26 diagnostic variables, classified in terms of their direction of impact

( $S$ denotes a stimulant, D - destimulant, no nominants were identified):

- own municipal revenues per inhabitant in PLN (S),

- spending on public roads as \% of total expenditure (S),

- total expenditure per inhabitant in PLN (S),

- education expenditure per inhabitant in PLN (S)

- expenditure on culture and national heritage protection per inhabitant in PLN (S),

- expenditure on climate protection per capita in PLN (D),

- people using the water supply network as \% of the total population (S),

- people using the sewerage system as \% of the total population (S),

- people using the gas supply network in \% of the total population (D),

- length of the water supply network per $100 \mathrm{~km}^{2}$ (S), 
- total water consumption in households per inhabitant in $\mathrm{m}^{3}(\mathrm{~S})$,

- average usable floor area of a dwelling in $\mathrm{m}^{2}$ (D),

- average usable floor area of a dwelling per person in $\mathrm{m}^{2}$ (D),

- number of dwellings per 1000 inhabitants (S),

- number of companies per 10,000 inhabitants (S),

- foundations, associations and social organisations per 1000 inhabitants (S),

- number of newly registered companies per 10,000 inhabitants of working age (S),

- deregistered companies as \% of all companies (S),

- registered unemployed as \% the working age population (S),

- industrial use of water as \% of total water abstractions (S),

- water consumption per inhabitant in $\mathrm{m}^{3}(\mathrm{~S})$,

- financing and co-financing of programmes and UE projects as \% of municipal revenues (S),

- total value of projects according to operational programmes and financing sources per inhabitant in PLN (S),

- bicycle paths per $100 \mathrm{~km}^{2}$ in $\mathrm{km}(\mathrm{S})$,

- ratio of gross floor area of non-residential buildings completed to usable floor area of dwellings completed (S),

- bed spaces per $100 \mathrm{~km}^{2}(\mathrm{~S})$.

A variable is classified into one of the three categories based on the researcher's experience and expertise. In classifying the variables - in view of its planned use - the authors took into consideration their correlation with the level of municipal revenues per inhabitant (positively correlated variables were categorised as stimulants, negatively correlated ones - as destimulants; nominants were not identified). Variable transformation consisted in converting destimulants into stimulants by changing their sign in order to obtain a set of uniform diagnostic variables.

Normalisation involves changing diagnostic variables (usually expressed in different units and taking on values in different ranges) to make them as comparable as possible. In this study normalisation was conducted using an approach based on the spatial median, in which the model is treated as an integral whole, and the strength and direction of relationships between diagnostic variables is accounted for while the impact of incidental outliers on the final result is minimised (see Młodak 2006b, 2009).

Let $X_{1}, X_{2}, \ldots, X_{m}$ denote a set of diagnostic variables, $x_{i j}$ - an observation of variable $X_{j}$ for $i$-th object, $\gamma_{i}=\left(x_{i 1}, x_{i 2}, \ldots, x_{i m}\right)$ - a vector of observations of variables for object $i, i=1,2, \ldots, n$, $\mathrm{j}=1,2, \ldots, m$, ( $n$ - number of objects, $m$ - number of diagnostic variables). The spatial median is then defined as vector $\Theta=\left(\theta_{1}, \theta_{2}, \ldots, \theta_{m}\right) \in R^{m}$, which minimizes the sum of Euclidean distances from points $\gamma_{1}, \gamma_{2}, \ldots, \gamma_{n}$, i.e. satisfies the following optimization equation:

$$
\sum_{i=1}^{n} \sqrt{\sum_{j=1}^{m}\left(x_{i j}-\theta_{j}\right)^{2}}=\min _{Y \in R^{m}} \sum_{i=1}^{n} \sqrt{\sum_{j=1}^{m}\left(x_{i j}-y_{j}\right)^{2}}
$$

In order to improve the robustness of results and minimise the negative impact of outliers, a trimmed version of equation (1) was used, which means the summation over $k(k<n)$ was limited to the smallest partial distances. In our case, the $5 \%$-trimmed version was applied, i.e. $k=[0.95 n]$.

Normalisation performer using the trimmed spatial median is given by:

$$
z_{i j}:=\frac{x_{i j}-\tilde{\theta}_{j}}{1.4826 \cdot \operatorname{mãd}\left(x_{j}\right)}
$$


where: $\operatorname{mãd}\left(X_{j}\right)=\operatorname{med}_{i=1,2, \ldots, n}\left|x_{i j}-\tilde{\theta}_{j}\right|$, for $i=1,2, \ldots, n, j=1,2, \ldots, m$. (Lira et. al 2002; Młodak 2006a). Having normalised the diagnostic variables, it is possible to start constructing the taxonomic measure of development. Such a measure is an artificial, ideal construct to which other objects are compared. In this case, the reference object for the assessment of development was denoted symbol $\Psi$, described by vector $\Psi=\left(\psi_{1}, \psi_{2}, \ldots, \psi_{m}\right) \in \mathrm{R}^{\mathrm{m}}$ such that:

$$
\psi_{j}=\max _{j=1,2, \ldots, n} z_{i j}
$$

for each $j=1,2, \ldots, m$.

In the following step, it is necessary to determine the distance between each object and the reference object. It can be done using different measures of distance, e.g. the taxicab metric (also called Manhattan distance), Euclidean distance, median distance, etc. In this study the distance between Ŝth object and the reference object was defined as median distance:

$$
d_{i} \stackrel{\text { def }}{=} \operatorname{med}_{i=1,2, \ldots, n}\left|z_{i j}-\psi_{j}\right|
$$

for each $i=1,2, \ldots, n$.

The last stage of the procedure involves calculating the synthetic measure (also referred to as a metavariable). For ŝth object, it is defined as a function of its distance from the reference object specified for development:

$$
\mu_{i} \stackrel{\text { def }}{=} 1-\frac{d_{i}}{\operatorname{med}(d)+2.5 \operatorname{mad}(d)}
$$

for each $i=1,2, \ldots, n$, where $d=\left(d_{1}, d_{2}, \ldots, d_{m}\right)$. The constant 2.5 is sometimes known as the robust threshold value (Rousseeuw \& Leroy 1987). The measure expressed by equation (2) is largely resistant to outliers, which can distort final results. Measure $\mu$ can assume negative values. In such cases, it provides information about a considerable deviation of the object's value from others. The higher the value of $\mu$, the more favourable the situation of the object is with respect to a particular aspect of interest. In our study, the complex measure was characterised by the following descriptive statistics:

- arithmetic mean: 0.1425,

- minimum: -0.1058,

- lower quartile: 0.0774,

- median: 0.1221,

- upper quartile: 0.1777 ,

- maximum: 0.7016,

- variance: 0.0135 ,

- coefficient of variation: $81.7 \%$.

The minimum value was observed for the municipality of Brzyska, and the maximum one - for the town of Rzeszów. Figure 2 contains a box and whisker plot showing the variation in the values of the synthetic measure. 


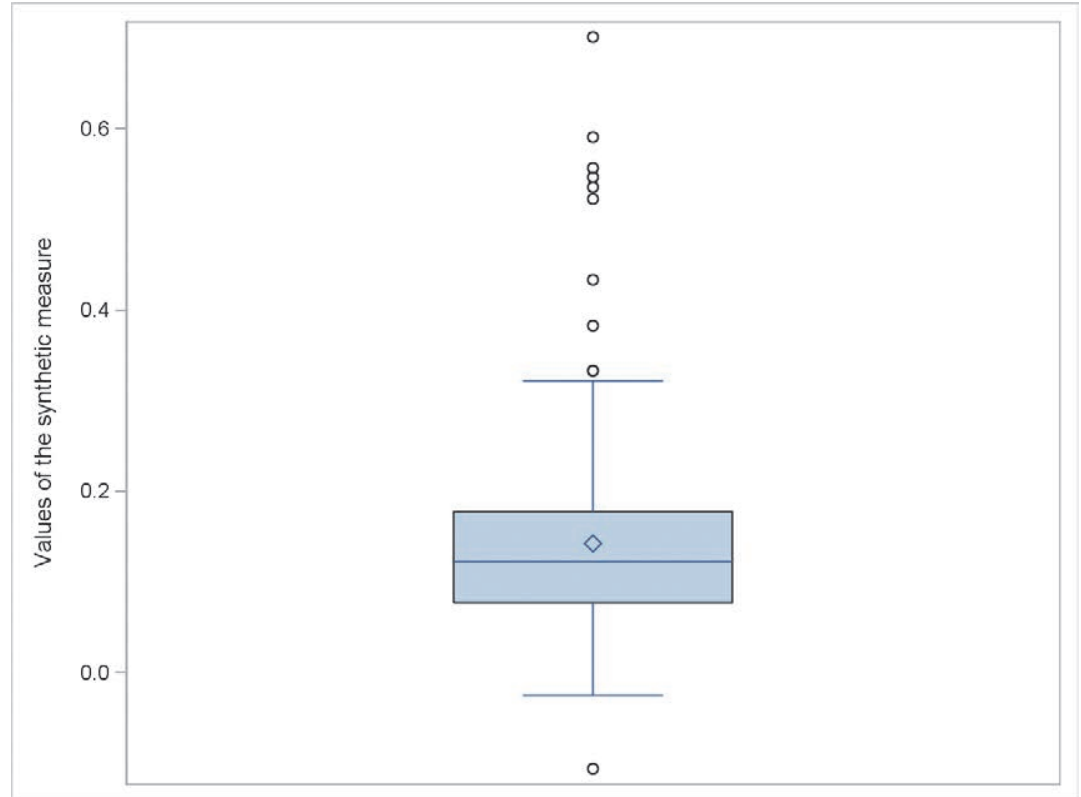

Figure 2. Distribution of the synthetic measure - box and whisker plot

As can be seen, the arithmetic mean (denoted by the diamond) is higher than the median (marked by the line inside the box). In addition, the $3^{\text {rd }}$ quartile (the upper edge of the box) is further away from the median than the $1^{\text {st }}$ quartile (lower edge of the box). This implies a right-skewed distribution of the complex measure (which is also indicated by the value of the asymmetry coefficient equal to 2.1194). There are also nine outliers in the high range of values (starting from the maximum whisker, they represent the following municipalities: the town of Rzeszów, Cisna, the town of Krosno, Solina, Lutowiska, the town of Przemyśl, the town of Tarnobrzeg, the town of Leżajsk and the town of Stalowa Wola, and one outlier in the low range of values - the municipality of Brzyska). The outliers are marked by circles and are found outside the typical range of variation of the synthetic measure marked by the whiskers. The outliers lie over 1.5 IQR from either edge of the box.

\section{The econometric model}

The core of the analysis undertaken in the study is the econometric model based on information about the location of companies belonging to special economic zones in Podkarpackie province. Out of a total of 160 municipalities in the province, such companies are found in 29 municipalities (18.1\% of the total). These companies belong to one of the three SEZs: Kraków Technological Park, Mielec Special Economic Zone and Tarnobrzeg Special Economic Zone; in the town of Krosno there are companies belonging to Kraków Technological Park and to Mielec Special Economic Zone. Given the spatial distribution of municipalities with companies belonging to SEZs and socio-demographic characteristics of these municipalities, it can be assumed that their possible impact within the province is relatively equal (see Fig. 3). 
The econometric model analysed in the study is given by the following equation:

$$
\text { Measure }=a_{0}+a_{1} \cdot K P T+a_{2} \cdot \text { Mielecka }+a_{3} \cdot \text { Tarnobrzeska }+a_{4} \cdot \text { Revenue }+\varepsilon
$$

where:

- Measure - the synthetic measure,

- KPT - the presence of companies belonging to Kraków Technological Park,

- Mielecka - the presence of companies belonging Mielec SEZ,

- Tarnobrzeska - the presence of companies belonging Tarnobrzeg SEZ,

- Revenue - municipal revenue per inhabitant in PLN,

- $\varepsilon$ - random effect,

- $a_{0}, a_{1}, a_{2}, a_{3}, a_{4}$ - model coefficients.

Variables KPT, Mielecka and Tarnobrzeska are binary variables. Each of them is equal to 1, if there are companies belonging to a given SEZ in a given municipality, otherwise, it is equal to 0 . For instance, in the case of the town of Krosno, KPT $=1$, Mielecka $=1$, whereas Tarnobrzeska $=0$.

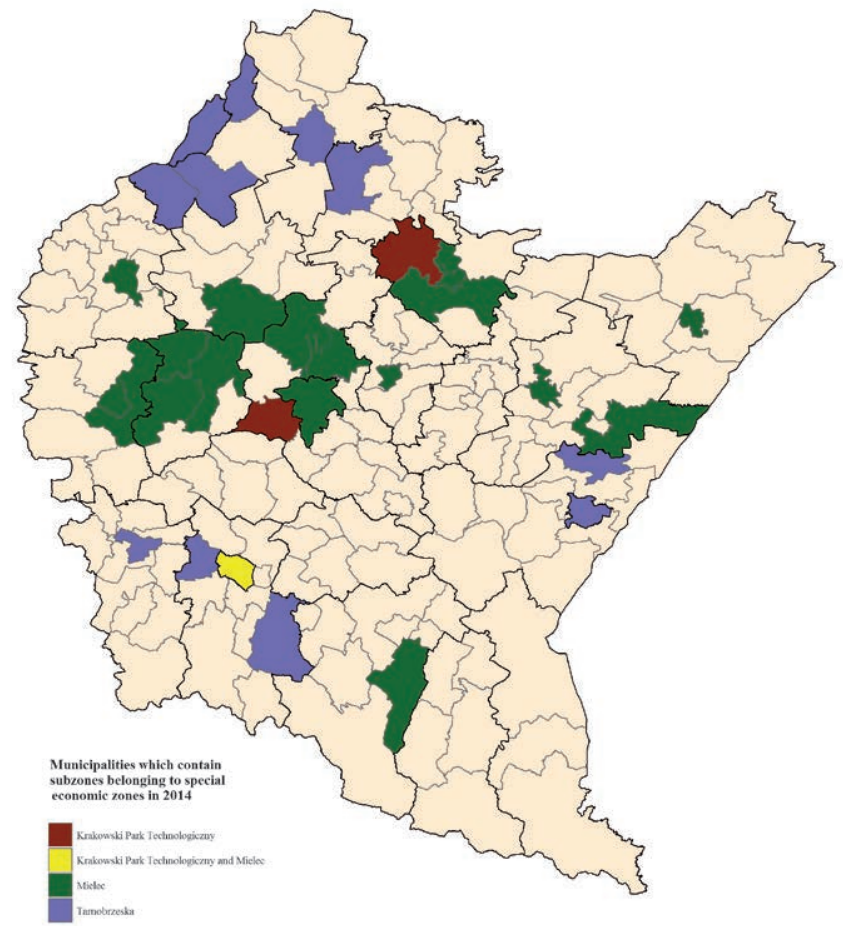

Figure 3. Municipalities of Podkarpackie province which contain subzones belonging to special economic zones 
Estimated model parameters are presented in Table 1.

Table 1. Estimated model parameters

\begin{tabular}{|l|c|c|c|c|}
\hline \multicolumn{1}{|c|}{ Variable } & $\begin{array}{c}\text { Estimated } \\
\text { parameter }\end{array}$ & Standard error & $\begin{array}{c}\text { Value } \\
\text { of t test }\end{array}$ & $\begin{array}{c}\text { Ex post significance } \\
\text { level for t test }\end{array}$ \\
\hline Intercept & -0.14475 & 0.03826 & -3.78 & 0.0002 \\
\hline KPT & 0.09394 & 0.06723 & 1.40 & 0.1643 \\
\hline Mielecka & 0.10813 & 0.02462 & 4.39 & $<0.0001$ \\
\hline Tarnobrzeska & 0.07983 & 0.02892 & 2.76 & 0.0065 \\
\hline Revenue & 0.00008 & 0.00001 & 7.06 & $<0.0001$ \\
\hline
\end{tabular}

As can be seen, variables Mielecka, Tarnobrzeska and Revenue are statistically significant. Only the KPT variable is not significant, which may be due to the relatively least importance of this SEZ in the province compared to the two other SEZs - companies belonging to this SEZ are only found in two municipalities, one of which is "shared" with companies belonging to Mielec SEZ. It is worth noting that the impact of municipal revenue per inhabitant on the socio-economic development is less significant than could be expected, in contrast to the significant effect of the two SEZs.

Tables 2 . and 3 present analysis of variance and quality indicators for the analysed model.

Table 2. Analysis of variance

\begin{tabular}{|l|c|c|c|c|c|}
\hline \multicolumn{1}{|c|}{ Errors } & $\begin{array}{c}\text { Degrees of } \\
\text { freedom }\end{array}$ & $\begin{array}{c}\text { Sum of } \\
\text { squares }\end{array}$ & $\begin{array}{c}\text { Mean } \\
\text { square }\end{array}$ & F value & $\begin{array}{c}\text { Ex post } \\
\text { significance } \\
\text { for F test }\end{array}$ \\
\hline Explained by regression & 4 & 0.86438 & 0.21609 & & \multirow{2}{*}{25.98} \\
Unexplained by regression & 155 & 1.28919 & 0.00832 & $<0.0001$ \\
\hline In total & 159 & 2.15357 & $\mathrm{x}$ & \\
\hline
\end{tabular}

Table 3. Quality indicators of the model

\begin{tabular}{|l|c|}
\hline \multicolumn{1}{|c|}{ Indicator } & Value \\
\hline RMSE & 0.0912 \\
\hline Dependent mean & 0.1425 \\
\hline Model's coefficient of variation (\%) & 64.0210 \\
\hline Coefficient of determination R2 & 0.4014 \\
\hline Adjusted coefficient of determination R2 & 0.3859 \\
\hline
\end{tabular}

RMSE is the root square of Mean Squared Error, i.e. the standard deviation of residuals. The model's coefficient of variation is the ratio of RMSE and the mean value of the dependent variable. It is clear that errors explained by regression are significant and show less variation than output values of the dependent variable. The value of the coefficient of determination is not very high, but sufficiently high to indicate a certain dependence between the variables of interest. As can be seen from Figure 4, this value is probably due to the fact that companies belonging to SEZs operate in a relatively small group of municipalities; as a result, most points representing municipalities which do not contain SEZs are found in the lower part of the chart. 


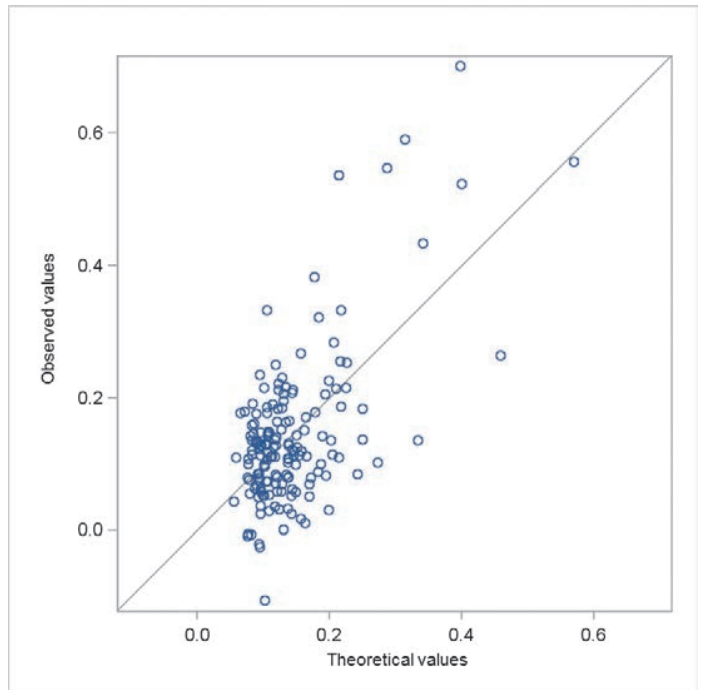

Figure 4. Theoretical vs observed values of the dependent variable

Of course, the model has certain deficiencies resulting, among other things, from the fact that the existence of SEZs was accounted for in a very limited way. However, in view of the absence of more detailed information about those companies and the dispersed location of the SEZs, it was the only option available.

\section{Conclusions}

The above analysis indicates that special economic zones can have a considerable impact on the socio-economic development of municipalities which are home to companies that belong to these zones. This impact is evident when a SEZ covers a sufficiently large area and is characterized by a certain level of business activity. In the case of Podkarpackie province, this is particularly true of the two most active zones: Mielec SEZ and Tarnobrzeg SEZ. The impact of Kraków Technological Park is less significant, because companies associated with it are only found in Krosno (where there are also companies belonging to Mielec SEZ) and the urban-rural municipality of Boguchwała. It is also worth noting that companies belonging to SEZs are located in many municipalities characterized by a lower level of development, which contributed to closing the gap between different areas in this respect. The analysis has demonstrated that municipal revenue per inhabitant (like per capita GDP at a macroeconomic level) is usually not the best, and certainly not the only indicator of the standard of living at the regional or local level.

As already mentioned, the analytic steps described in the article are an attempt to assess the impact of the presence of business entities functioning as part of SEZs on the development of municipalities where they are located. Given the fact that the organisational and spatial form of SEZs does not coincide with the borders of local territorial units, it is very difficult to find common ground for analysis. This study was based on freely available information. However, judging by the estimates from the model and research intuition, the accuracy of the results could be improved by 
getting access to administrative data about companies belonging to SEZs, particularly to data about their economic and financial situation, about taxes paid to municipalities, the companies' impact on the local labour market, barter or sponsorship agreements for the benefit of local government and communities and the value of such contributions, etc. These are a few of the challenging and relevant studies that could be conducted in the near future.

\section{Acknowledgements}

All calculations in tables and figures were produced using SAS Enterprise Guide 4.3.

\section{References}

Akinci G., Crittle J., 2008. Special economic zones: Performance, lessons learned, and implications for zone development. Washington: The World Bank.

Ambroziak A.A., 2009. Efekty funkcjonowania specjalnych stref ekonomicznych w Polsce, Zeszyty Naukowe Kolegium Gospodarki Światowej Szkoły Głównej Handlowej w Warszawie, Warszawa, no. 24, pp. 111-141.

Bräutigam D., Tang X., 2014. Going Global in Groups: Structural Transformation and China's Special Economic Zones Overseas. World Development, vol. 63, pp. 78 - 91.

Domański B., Gwosdz K. (eds.), 2005. Dziesięć lat doświadczeń pierwszej polskiej specjalnej strefy ekonomicznej Mielec 1995-2005, Instytut Geografii i Gospodarki Przestrzennej Uniwersytetu Jagiellońskiego i Agencja Rozwoju Przemysłu S.A. Oddział w Mielcu.

Farole T., Akinci G., (eds.), 2011. Special Economic Zones. Progress, Emerging Challenges, and Future Directions. Washington: The International Bank for Reconstruction and Development/The World Bank.

Golik D., Kątnik-Prokop J., 2014. Funkcjonowanie specjalnych stref ekonomicznych w Polsce, Studia Ekonomiczne, no. 166, Polityka gospodarcza w okresie transformacji i kryzysu, Katowice: Uniwersytet Ekonomiczny, pp. 180-193.

Józefowski T., Szymkowiak M., 2015. Wykorzystanie uogólnionej miary odległości do porzq̨dkowania liniowego powiatów województwa podkarpackiego w świetle funkcjonowania specjalnej strefy ekonomicznej Euro-Park Mielec [in:] Taksonomia 24, Klasyfikacja i analiza danych - teoria i zastosowania, Prace Naukowe Uniwersytetu Ekonomicznego we Wrocławiu, no. 384, pp. 135-143.

Kapusta F., 1997. Gmina jako mikroregion przedsiębiorczości na przykładzie Kobierzyc [in:] Przedsiębiorczość w agrobiznesie a rozwój terenów wiejskich. Academy of Agriculture in Kraków, Department of Economics in Rzeszów, Trzcinica, pp. 355-366.

Kołomycew A., 2008. Tarnobrzeska Specjalna Strefa Ekonomiczna jako instrument rozwoju lokalnego (na przykładzie powiatu tarnobrzeskiego). Zeszyty Naukowe Zakładu Europeistyki Wyższej Szkoły Informatyki i Zarządzania w Rzeszowie: szkice z dziedzin nauki, Rzeszów, no. 2, pp. 51-75.

Kryńska E., 2000. Polskie specjalne strefy ekonomiczne-zamierzenia i efekty. Warszawa: Wydawnictwo Naukowe Scholar.

Kudełko J., 2006. Efekty funkcjonowania specjalnych stref ekonomicznych w Polsce jako instrumentu polityki regionalnej. Kraków: Zeszyty Naukowe Akademii Ekonomicznej, No. 709. 
Lira J., Wagner W., Wysocki F., 2002. Mediana w zagadnieniach porzq̨dkowania obiektów wielocechowych [in:] J. Paradysz (ed.) Statystyka regionalna w służbie samorządu lokalnego i biznesu, Internetowa Oficyna Wydawnicza Centrum Statystyki Regionalnej, Poznań: Uniwersytet Ekonomiczny, pp. 87 - 99.

Lizińska W., Marks-Bielska R., 2013. Efekty funkcjonowania specjalnych stref ekonomicznych w Polsce w kontekście realizacji celów ich tworzenia oraz wykorzystywanej pomocy publicznej. Optimum. Studia ekonomiczne, no. 2 (62), pp. 92 - 105.

Malina A., Zeliaś A., 1998. On Building Taxonometric Measures on Living Conditions, Statistics in Transition, vol. 3, no. 3, pp. $523-544$.

Miłaszewicz D., 2011. Specjalne strefy ekonomiczne jako narzędzie modernizacji gospodarki. Studia i Prace Wydziału Nauk Ekonomicznych i Zarządzania, Szczecin, no. 22, pp. 7 - 34.

Młodak A., 2006a. Analiza taksonomiczna w statystyce regionalnej. Warszawa: Centrum Doradztwa i Informacji DIFIN.

Młodak A., 2006b. Multilateral normalisations of diagnostic features, Statistics in Transition, vol. 7, no. 5, pp. $1125-1139$.

Młodak A., 2009. Zróżnicowanie kapitału ludzkiego na rynku pracy - analiza taksonomiczna. Wiadomości Statystyczne, R. LIV, No. 11/2009, pp. $53-69$.

Młodak A., Józefowski T., Wawrowski Ł., 2016. Zastosowanie metod taksonomicznych w estymacji wskaźników ubóstwa. Wiadomości Statystyczne, R. LXI, No. 2/2016, pp. 1 - 24.

Nazarczuk J.M., 2013. Efektywność pomocy publicznej udzielonej w specjalnych strefach ekonomicznych w Polsce. Olsztyn: Uniwersytet Warmińsko-Mazurski.

Omar K., Stoever W.A., 2008. The Role of Technology and Human Capital in the EPZ Life-cycle. Translation Corporations, vol. 17, no. 2, pp. $229-240$.

Pastusiak R. 2011. Specjalne strefy ekonomiczne jako stymulator rozwoju gospodarczego. Łódź: Wydawnictwo Uniwersytetu Łódzkiego.

Pastusiak R., Keller J., 2014. Wpływ Specjalnych Stref Ekonomicznych na gospodarkę Polski. Zeszyty Naukowe Uniwersytetu Szczecińskiego. no. 80, Finances, Financial Markets, Insurance, no. 65, pp. 167-177.

Rousseeuw P.J., Leroy A.M., 1987. Robust Regression and Outlier Detection [in:] J. Wiley and Sons Inc., New York, Chichester, Brisbane, Toronto, Singapore. 
http://rcin.org.pl 